\title{
KUALITAS SENSORIS ES KRIM YANG DITAMBAHKAN BUAH NAGA MERAH (Hylocereus polyrhizus)
}

\author{
Rumiati Umar, S.E. Siswosubroto*, Meilani R. Tinangon, Afrisa Yelnetty
}

Fakultas Peternakan Universitas Sam Ratulangi Manado, 95115

\begin{abstract}
ABSTRAK
Penelitian dilakukan untuk mengetahui penambahan buah naga merah terhadap kualitas sensoris es krim. Penelitian ini menggunakan susu UHT, susu skim milk, whipped cream, agar-agar bubuk, aquades, gula pasir, dan kuning telur dan buah naga. Rancangan yang digunakan adalah rancangan acak lengkap (RAL) yang terdiri dari 5 perlakuan dan 40 ulangan, variabel yang dianalisis pada penelitian ini adalah kualitas sensoris yang terdiri dari warna, aroma, tekstur, cita rasa. Data yang diperoleh dianalisis menggunakan anova. Apabila terdapat perbedaan antar perlakuan dilanjutkan dengan uji BNJ. Hasil penelitian ini menunjukkan bahwa buah naga merah pada perlakuan R0, R1， R2， R3， dan R4 memberikan pengaruh sangat nyata $(\mathrm{P}<0,01)$ terhadap warna, aroma, tekstur, dan cita rasa pada es krim. Berdasarkan hasil dan pembahasan bahwa penambahan buah naga merah $40 \%$ memberikan kualitas sensoris es krim yang baik.
\end{abstract}

Kata Kunci: Es krim, Buah Naga Merah, Sifat Sensoris

\begin{abstract}
SENSORY QUALITY OF ICE CREAM ADDED BY RED DRAGON FRUIT (Hylocereus polyrhizus). The study was conducted to determine the
\end{abstract}

*Kosepondensi (corresponding author) Email: edmund1403@gmail.com addition of red dragon fruit on the sensory quality of ice cream. This study used UHT milk, milk of skim milk, whipped cream, gelatin powder, aquades, granulated sugar, egg yolks and 16 dragon fruit. The design used was a Completely Randomized Design (CRD) consisting of 5 treatments and 40 replications. The variables analyzed in this study were sensory quality (color, aroma, texture, taste). Data obtained were analyzed using ANOVA. The significant differences between treatments were tested by the BNJ test. The results indicated that the red dragon fruit in the treatments of R0, $\mathrm{R} 1, \mathrm{R} 2, \mathrm{R} 3$, and R4 gave a very significant influence $(\mathrm{P}<0.01)$ on color, aroma, texture, and taste of ice cream and the results of BNJ's further test showed R4 treatment (40\% red dragon fruit) had the best results on the sensory properties of ice cream. Therefore, it was concluded that the addition of $40 \%$ red dragon fruit provided good sensory quality of ice cream.

Keywords: Ice cream, Red Dragon Fruit, Sensory Properties

\section{PENDAHULUAN}

Susu merupakan minuman bergizi tinggi yang dihasilkan ternak perah seperti sapi perah dan kambing perah. Susu sangat mudah rusak dan tidak tahan disimpan kecuali telah menerima perlakuan khusus contohnya pengawetan dan pengolahan. Susu segar yang dibiarkan pada suhu ruang 
pada beberapa waktu akan mengakibatkan kerusakan diantaranya terjadi penggumpalan dibagian permukaan berupa krim susu, yang diakibatkan oleh bakteri perusak susu yang bertebaran diudara sekitar kandang. Pencegahan kerusakan dapat dilakukan dengan penanganan dan pengolahan susu yang tepat, guna mempertahankan nilai gizi salah satu pengolahan yang dapat dilakukan adalah dengan mengolah susu menjadi es krim.

Es Krim merupakan produk olahan susu yang digemari semua kalangan masyarakat, baik yang usia muda maupun usia lanjut. Es krim mempunyai rasa yang lezat, warnanya menarik dan teksturnya yang lembut. Es krim merupakan jenis makanan yang bernilai gizi tinggi yaitu mengandung protein, lemak, karbohidrat, vitamin dan mineral. Kandungan lemak dalam es krim tiga sampai empat kali lebih banyak dari pada susu dan setengah dari total bahan padatnya berupa gula. Pembuatan es krim dapat divariasikan dengan menambahkan berbagai jenis buahbuahan salah satunya adalah buah naga merah.

Buah naga (Dragon Fruit) merupakan tanaman holtikultura yang baru di budidayakan di Indonesia dengan warna buah merah yang menyala dan bersisik hijau. Buah ini memiliki bentuk yang sangat unik dan cukup memikat untuk di lihat. Bentuk fisiknya mirip dengan buah nanas hanya saja buah ini memiliki sulur pada kulitnya. Buah naga merah memiliki biji kecil berwarna hitam yang sangat lembut dan lunak (Khairunnas dan Tety, 2011). Buah naga atau dragon fruit mempunyai kandungan zat bioaktif yang bermanfaat bagi tubuh di antaranya antioksidan (dalam asam askorbat, betakaroten, dan antosianin), serta mengandung serat pangan dalam bentuk pektin. Selain itu dalam buah naga terkandung beberapa mineral seperti kalsium, phosphor, dan besi. Vitamin yang terdapat di dalam buah naga antara lain vitamin B1, vitamin B2, vitamin B3 dan vitamin C (Pratomo, 2008 dalam Farikha et al., 2013). Berat buah naga merah mencapai 500 gram per buah, dan memiliki tingkat kemanisan 13-15 briks (Umayah dan Amrun 2007).

Berdasarkan hal di atas maka telah dilakukan penelitian pembuatan es krim dengan penambahan buah naga merah untuk mengetahui kualitas sensoris es krim. Tujuan dari penelitian ini yaitu untuk mengetahui bagaimana pengaruh penambahan buah naga merah terhadap kualitas sensoris es krim.

\section{MATERI DAN METODE PENELITIAN}

Penelitian ini dilaksanakan di Laboratorium Teknologi Hasil Ternak 
Fakultas Peternakan Universitas Sam Ratulangi, Kota Manado pada bulan Februari - April 2018.

\section{Materi Penelitian}

Bahan dasar dalam penelitian ini adalah: Susu segar 5150 gram, susu skim milk 1000 g, whipped cream 1000 g, agaragar bubuk 5 sachet, aquades 750 g, gula pasir 1000 g, kuning telur 20 butir, dan buah naga dengan masing-masing konsentrasi $10 \%$ dari jumlah susu, $20 \%$ dari jumlah susu, 30\% dari jumlah susu, dan $40 \%$ dari jumlah susu.

\section{Prosedur Pembuatan Es Krim Buah Naga Merah}

Proses pembuatan es krim buah naga merah di mulai dengan menyiapkan alat dan bahan yang di perlukan, timbang semua bahan sesuai kebutuhan, gula pasir dan kuning telur di kocok menggunakan mixer hingga mengental dan berwarna agak putih. Susu UHT, susu skim milk, dan whippy cream di mixer sampai tercampur menjadi adonan. Agar-agar dan air (150 mL) di didihkan, lalu masukan adonan gula telur dan adonan susu UHT, susu skim milk, whippy cream aduk merata selama 15 menit, setelah itu di angkat dan dituang di dalam wadah-wadah yang telah disiapkan, diamkan hingga dingin, masukan buah naga merah dengan masing-masing konsentrasi 100 g, 200 g, $300 \mathrm{~g}$ dan $400 \mathrm{~g}$ kemudian mixer masingmasing adonan yang telah di tambahkan buah naga merah tersebut hingga tercampur rata selama 15 menit. Adonan kemudian dimasukkan ke dalam freezer selama minimum 4 jam pembekuan, setelah itu keluarkan adonan dari dalam freezer lalu mixer kembali dan masukan lagi kedalam freezer selama 2,5 jam, mixer kembali kemudian setelah itu es krim dimasukkan ke dalam cup-cup yang telah disiapkan

Tabel 1. Formulasi Es Krim Dengan Penambahan Buah Naga Merah

\begin{tabular}{lccccc}
\hline \multicolumn{1}{c}{ Bahan } & \multicolumn{5}{c}{ Perlakuan } \\
\cline { 2 - 6 } & R0 & R1 & R2 & R3 & R4 \\
\hline Susu UHT (g) & 1030 & 1030 & 1030 & 1030 & 1030 \\
Susu skim milk (g) & 200 & 200 & 200 & 200 & 200 \\
Whipped cream (g) & 200 & 200 & 200 & 200 & 200 \\
Agar-agar (g) & 7 & 7 & 7 & 7 & 7 \\
Telur (butir) & 4 & 4 & 4 & 4 & 4 \\
Gula Pasir (g) & 200 & 200 & 200 & 200 & 200 \\
Aquades (mL) & 150 & 150 & 150 & 150 & 150 \\
Buah naga merah (\%) & 0 & 10 & 20 & 30 & 40 \\
\hline
\end{tabular}


sebanyak 40 cup untuk setiap perlakuan. Simpan kembali dalam freezer hingga membeku dan jadilah es krim buah naga merah.

\section{Metode Penelitian}

Penelitian ini dilaksanakan melalui suatu percobaan dengan menggunakan rancangan acak lengkap (Steel dan Torrie, 1994) dengan 5 perlakuan dan ulangan sebanyak 4 kali. Pengukuran data organoleptik dengan uji hedonik menggunakan panelis 40 panelis tak terlatih (Soekarto dan Hubbies, 1992).

Formulasi perlakuan dalam penelitian ini disusun sebagai berikut:

$\mathrm{P} 0=$ Tanpa buah naga merah

P1=Penambahan buah naga merah dengan

konsentrasi $10 \%$ dari jumlah susu

P2=Penambahan buah naga merah dengan konsentrasi $20 \%$ dari jumlah susu

P3=Penambahan buah naga merah dengan konsentrasi $30 \%$ dari jumlah susu

P4=Penambahan buah naga merah dengan konsentrasi $40 \%$ dari jumlah susu

\section{Variabel Penelitian}

Penelitian ini menggunakan uji organoleptik dengan skala hedonik, di mana panelis yang digunakan adalah panelis tidak terlatih sebanyak 40 orang.

\section{Prosedur Pengujian}

\section{Warna}

Warna merupakan parameter utama dalam menentukan tingkat konsumen, karena suatu produk dikatakan menarik apabila memiliki warna yang di sukai oleh konsumen. Peranan itu sesuai dengan pernyataan Simanjuntak et al. (2014), di mana warna mempunyai arti dan peranan sangat penting terhadap komoditas pangan terutama dalam daya tarik, tanda pengenal dan atribut mutu.

Sampel yang diuji ditempatkan di dalam wadah dan setiap sampel diberi kode. Panelis diminta untuk mengamati warna sampel es krim buah naga merah kemudian memberikan penilaian dan menuliskannya pada lembar format uji.

Kriteria penilaian untuk warna es krim buah naga merah adalah sebagai berikut:

$7=$ Sangat menarik

$6=$ Menarik

5= Agak menarik

$4=$ Netral

$3=$ Agak tidak menarik

$2=$ Tidak menarik

$1=$ Sangat tidak menarik

\section{Aroma}

Di dalam industri pangan pengujian terhadap bau / aroma dianggap penting karena dengan cepat dapat memberikan hasil penilaian terhadap produk tentang di terima atau tidaknya suatu produk (Soekarto dan Hubeis, 1992). 


\author{
Aroma es krim buah naga merah \\ diuji secara organoleptik. Prosedur \\ pengujian untuk aroma yaitu panelis \\ mengambil es krim buah naga merah yang \\ telah disiapkan kemudian panelis \\ menghirup aroma dari es krim buah naga \\ merah tersebut, lalu mengisi lembaran \\ format uji sesuai dengan tingkat kesukaan. \\ Kriteria penilaian untuk aroma adalah \\ sebagai berikut: \\ 7= Sangat suka \\ $6=$ Suka \\ 5= Agak suka \\ $4=$ Netral \\ 3= Agak tidak suka \\ $2=$ Tidak suka \\ $1=$ Sangat tidak suka
}

\section{Tekstur}

Indra yang digunakan untuk menilai tekstur adalah indra peraba. Penilaian didasarkan pada ransangan mekanis, fisik dan kimiawi, dari sinilah akan dihasilkan kesan rabaan (Hidayat et al., 2009).

Prosedur pengujian untuk tekstur yaitu panelis mengambil sampel es krim buah naga merah menilai kekasaran dan kehalusan es krim, kemudian mengisi penilaian dalam lembar format uji. Kriteria penilaian tekstur es krim buah naga merah adalah sebagai berikut:

$7=$ Sangat halus

$6=$ Halus

$5=$ Agak halus
$4=$ Netral

3= Agak kasar

$2=$ Kasar

$1=$ Sangat kasar

\section{Cita Rasa}

Cita rasa es krim buah naga merah diuji secara organoleptik. Bahan disiapkan secara acak setiap pindahan sampel berikutnya dengan meminum air putih dan memakan mentimun untuk menetralkan alat indra dalam rongga mulut. Selanjutnya panelis mengambil es krim buah naga merah yang telah disajikan, kemudian es krim buah naga merah dimakan atau dicicipi sesuai dengan tingkat kesukaan dan diisi dalam lembar format uji. Kriteria penilaian untuk cita rasa es krim buah naga merah adalah sebagai berikut :

$7=$ Sangat enak

$6=$ Enak

$5=$ Agak enak

$4=$ Netral

$3=$ Agak tidak enak

$2=$ Tidak enak

$1=$ Sangat tidak enak

\section{Prosedur Analisis}

Data yang diperoleh dianalisa dengan analisis keragaman (Steel dan Torie, 1994), dan jika ada yang berbeda nyata diuji lanjut dengan menggunakan uji beda nyata jujur (BNJ). 


\section{HASIL DAN PEMBAHASAN}

Hasil pengamatan uji sensoris es krim dengan penambahan buah naga merrah (hylocereus polyrhizus) disajikan dalam Tabel 2.

\section{Warna Es Krim Buah Naga Merah}

Data hasil pengamatan untuk uji sensoris es krim dengan penambahan buah naga merah terhadap warna es krim dapat dilihat pada Tabel 2. Data yang dihasilkan menunjukan bahwa tingkat kesukaan panelis terhadap warna es krim dengan penambahan buah naga merah pada konsentrasi yang berbeda memberikan kisaran rataan 4,8 (agak menarik) sampai 6,1 (menarik).

Hasil analisis sidik ragam menunjukan bahwa perlakuan penambahan buah naga merah dengan konsentrasi yang berbeda berpengaruh sangat nyata $(\mathrm{P}<0,01)$ terhadap warna es krim. Berdasarkan hasil uji lanjut menggunakan uji BNJ menunjukan bahwa perlakuan R0 berbeda sangat nyata $(\mathrm{P}<0,01)$ terhadap $\mathrm{R} 1, \mathrm{R} 2, \mathrm{R} 3$ dan R4. Perlakuan R1 berbeda sangat nyata ( $\mathrm{P}<0,01$ ) dengan R2, R3 dan R4. Perlakuan R2 tidak berbeda nyata $(\mathrm{P}>0,01)$ dengan $\mathrm{R} 3$ tapi berbeda sangat nyata $(\mathrm{P}<0,01)$ dengan R4. Data hasil uji sensoris warna es krim menunjukan bahwa penambahan buah naga merah $40 \%$ lebih disukai panelis dibandingkan es krim yang ditambahkan buah naga merah $10 \%, 20 \%$, dan $30 \%$. Tingkat kesukaan terhadap warna es krim yang diberikan panelis diduga karena buah naga merah mengandung pigmen antosianin yang memberikan warna merah yang menarik pada es krim. Warna merah pada es krim lebih menarik dibandingkan warna es krim tanpa buah naga merah. Demikian juga diamati pada data R1, R2, dan R3. Panelis memberikan penilaian tingkat kesukaan warna lebih tinggi pada perlakuan R3 dibandingkan dengan R1. Daya tarik warna merah yang ditampilkan pada R3 memberikan kesan yang paling menarik dibandingkan warna merah pada perlakuan R1. Buah naga merah berwarna menarik, semakin merah warnanya semakin banyak kandungan betakarotennta (Markakis, 1982 dalam Farikha et al., 2013).

Antosianin merupakan salah satu bagian penting dalam kelompok pigmen setelah klorofil. Antosiani larut dalam air, menghasilkan warna merah dan tersebar luas dalam buah, kulit dan bunga. Warna alami dari buah naga merah memberikan intensitas warna merah yang stabil pada es krim (Saati et al., 2009 dalam Ekawati et al., 2015).

\section{Aroma Es Krim Buah Naga Merah}

Data hasil pengamatan untuk sifat sensoris es krim dengan penambahan buah naga merah terhadap 
Tabel 2. Rataan Nilai Sensoris Es Krim dengan Penambahan Buah Naga Merah

\begin{tabular}{cccccc}
\hline \multirow{2}{*}{ Variabel } & \multicolumn{5}{c}{ Perlakuan penambahan buah Naga Merah (\%) } \\
\cline { 2 - 6 } & $\mathrm{R} 0$ & $\mathrm{R} 1$ & $\mathrm{R} 2$ & $\mathrm{R} 3$ & $\mathrm{R} 4$ \\
\cline { 2 - 6 } & 0 & 10 & 20 & 30 & 40 \\
\hline Warna & $4,8^{\mathrm{a}}$ & $5,3^{\mathrm{b}}$ & $5,7^{\mathrm{c}}$ & $5,8^{\mathrm{c}}$ & $6,1^{\mathrm{d}}$ \\
Aroma & $4,9^{\mathrm{a}}$ & $5,4^{\mathrm{ab}}$ & $5,5^{\mathrm{b}}$ & $5,8^{\mathrm{b}}$ & $5,9^{\mathrm{b}}$ \\
Tekstur & $4,9^{\mathrm{a}}$ & $5,3^{\mathrm{ab}}$ & $5,5^{\mathrm{b}}$ & $5,6^{\mathrm{bc}}$ & $6,1^{\mathrm{c}}$ \\
Cita Rasa & $4,8^{\mathrm{a}}$ & $5,2^{\mathrm{ab}}$ & $5,6^{\mathrm{bc}}$ & $6,1^{\mathrm{cd}}$ & $6,4^{\mathrm{d}}$ \\
\hline
\end{tabular}

Keterangan :Superskrip yang berbeda pada baris yang sama artinya berbeda sangat nyata $(\mathrm{P}<0,01)$

kualitas aroma es krim, dapat dilihat pada

Tabel 2. Rataan tingkat kesukaan panelis terhadap aroma es krim berkisar antara 4,9 (netral) sampai 5,9 (suka).

Berdasarkan hasil analisis sidik ragam menunjukan bahwa perlakuan penambahan buah naga merah dengan konsentrasi $10-40 \%$ memberikan pengaruh sangat berbeda nyata $(\mathrm{P}<0.01)$ terhadap tingkat kesukaan aroma es krim dibandingkan dengan tidak ditambahakan buah naga merah. Hasil uji lanjut menggunakan uji BNJ menunjukan bahwa perlakuan R0 berbeda sangat nyata $(\mathrm{P}<0.01)$ dengan R2, R3 dan R4 tapi tidak berbeda nyata $(\mathrm{P}>0.01)$ dengan $\mathrm{R} 1$. Perlakuan R1 tidak berbeda nyata $(\mathrm{P}>0.01)$ dengan R2, R3, dan R4.

Penambahan buah naga merah $0 \%$ sampai $10 \%$ belum memberikan perbedaan terhadap tingkat aroma. Perbedaan tingkat aroma muncul ketika buah naga merah ditambahkan pada es krim sebanyak 20\%, $30 \%$ dan $40 \%$. Hal ini karena panelis menyatakan agak suka terhadap aroma es krim, hal ini dikarenakan bahan utama yang digunakan dalam pembuatan es krim ini adalah susu. Sehingga aroma yang sangat terasa pada es krim yaitu aroma susu. Namun seiring dengan peningkatan penambahan buah naga merah berpengaruh terhadap aroma es krim. Hal ini disebabkan karena pada dasarnya aroma buah naga sulit untuk dideskripsi, karena buah naga memiliki aroma yang sama yaitu aroma alami dari buah naga itu sendiri.

Aroma merupakan indikator yang memberikan hasil penilaian yang diterima atau tidaknya produk tersebut. Namun aroma atau bau itu sendiri sukar untuk diukur, sehingga biasanya menimbulkan banyak pendapat berlainan dalam menilai kualitas aroma (Wahyuni 2012).

\section{Tekstur Es Krim Buah Naga Merah}

Data hasil pengamatan untuk uji sensoris es krim dengan penambahan buah naga merah terhadap tekstur es krim, dapat dilihat pada Tabel 2. Dari data hasil pengamatan menunjukan bahwa tingkat 
kesukaan panelis terhadap tekstur es krim berada pada kisaran 4,9 (agak halus) sampai 6,1 (halus).

Hasil analisis sidik ragam menunjukan bahwa perlakuan penambahan buah naga merah dengan konsentrasi yang berbeda berpengaruh sangat nyata $(\mathrm{P}<0,01)$ terhadap tekstur es krim yang dihasilkan. Berdasarkan hasil uji lanjut menggunakan uji BNJ menunjukan bahwa perlakuan R0 tidak berbeda nyata $(\mathrm{P}>0,01)$ dengan $\mathrm{R} 1$ tapi berbeda sangat nyata $(\mathrm{P}<0,01)$ dengan R2, R3 dan R4. Perlakuan R2 tidak berbeda nyata $(\mathrm{P}>0,01)$ dengan $\mathrm{R} 3$ tapi berbeda sangat nyata $(\mathrm{P}<0,01)$ dengan $\mathrm{R} 4$. Perlakuan R3 tidak berbeda nyata $(\mathrm{P}>0,01)$ dengan R4.

Penambahan $30 \%-40 \%$ buah naga merah memberikan tekstur es krim yang lebih halus atau lembut dibandingkan yang tidak ditambahkan buah naga merah, sejalan dengan yang dikatakan Cahyono (2009) bahwa daging buah naga memiliki serat yang halus atau lembut dan didalam daging buah naga itu sendiri terdapat bijibiji hitam yang banyak dan memiliki ukuran sangat kecil. Tekstur es krim juga di pengaruhi oleh ukuran dari Kristal es, globula lemak, gelembung udara, dan Kristal laktosa. Tekstur es krim yang baik adalah smooth (halus / lembut), tidak keras dan tampak mengkilap (Suprayitno et al., 2001).

\section{Cita Rasa Es Krim Buah Naga Merah}

Data hasil pengamatan untuk sifat sensoris es krim dengan penambahan buah naga merah terhadap cita rasa es krim, dapat dilihat pada Tabel 2. Data menunjukan bahwa tingkat kesukaan panelis terhadap cuta rasa es krim dengan penambahan buah naga merah yang berbeda, terdapat pada kisaran rataan 4,8 (agak enak) sampai 6,4 (enak).

Hasil analisis sidik ragam menunjukan bahwa perlakuan penambahan buah naga merah dengan konsentrasi yang berbeda berpengaruh sangat nyata $(R<0,01)$ terhadap cita rasa es krim yang dihasilkan. Berdasarkan hasil uji lanjut menggunakan uji BNJ menunjukan bahwa perlakuan R0 tidak berbeda nyata $(\mathrm{P}>0,01)$ dengan $\mathrm{R} 1$ tapi berbeda sangat nyata $(\mathrm{P}<0.01)$ terhadap R2, R3, dan R4. Perlakuan R1 tidak berbeda nyata dengan R2 tapi berbeda sangat nyata $(\mathrm{P}<0,01)$ terhadap, $\mathrm{R} 3$, dan R4. Perlakuan R2 tidak berbeda nyata ( $P>0,01)$ denngan R3 tapi berbeda sangat nyata $(\mathrm{P}<0,01)$ terhadap R4. Perlakuan R3 tidak berbeda nyata $(\mathrm{P}>0,01)$ terhadap $\mathrm{R} 4$. Terdapat perbedaan R0, R1, R2, R3, R4 terhadap cita rasa seiring dengan semakin banyak penambahan buah naga merah pada es krim. Penambahan buah naga merah $40 \%$ pada es krim memberikan daya tarik tersendiri terhadap cita rasa dan disukai oleh panelis. Daging buah naga itu sendiri memiliki cita rasa yang manis, sedikit 
masam dan tekstur yang lunak (Cahyono, 2009).

\section{KESIMPULAN}

Berdasarkan hasil dan pembahasan bahwa penambahan buah naga merah $40 \%$ dalam es krim memberikan kualitas sensoris yang baik.

\section{DAFTAR PUSTAKA}

Cahyono, B. 2009. Sukses Bertanam Buah Naga. Jakarta : Pustaka Mina.

Ekawati, P., Rostianti, Syahraeni. 2015. Aplikasi ekstrak kulit buah naga sebagai pewarna alami pada susu kedelai dan santan. Jurnal Agrotekbis Vol. 2(3): 198-205.

Farikha, I., C. Anam, E. Widowati. 2013. Pengaruh jenis dan konsentrasi penstabil alami terhadap karakteristik fisikokimia sari buah naga merah (Hylocereus polyrhizus) selama penyimpanan. Jurnal Teknosains Vol 2(1): 30-38.

Hidayat, B, Nurbani, Sufiana. 2009. Character ization of modifiet cassava flour processed through partial pregelatinisation method. Jurnal Teknologi Industri dan Hasil Pertanian. Vol 2(4): 19-23.
Khairunnas dan E. Tety. 2011. Analisis kelayakan usaha tani buah naga di Pekanbaru. Jurnal Pekbis Vol.3(8): 579-585.

Simanjuntak, L., C. Sinaga, Fatimah. 2014. Ekstraksi pigmen antosianin dari kulit buah naga merah (Hylocereus polyrhizus). Jurnal Teknik Kimia USU. Vol 3(2): 25-29.

Soekarto, T. S dan N. Hubeis, 1992. Petunjuk Menggunakan Laboratorium Metode Penelitian Indrawi. Pusat Antar Universitas Pangan dan Gizi. IPB. Bogor.

Steel. R. D dan J. K. Torrie. 1991. Prinsip dan Prosedur statistika. PT Gramedia Pustaka Utama, Jakarta.

Suprayitno, E., H. Kartikaningsih dan S. Rahayu. 2001. Pembuatan es krim dengan menggunakan stabilisator Natrium Alginat dari Sargasum sp. Jurnal Makanan tradisional Indonesia Vol 1(3): 23-27.

Umayah, E., dan M. Amrun. 2007. Uji aktivitas antioksidan ekstrak buah naga (Hylocereus undatus) (Haw.) Britt. \& Rose, Jurnal Ilmu Dasar. Vol 8(1): 83-90

Wahyuni, Rekna. 2012. Pemanfaatan buah naga super merah (Hylocereus Costaricensis) dalam pembuatan jenang dengan penambahan daging buah yang berbeda. Jurnal Teknologi Pangan Vol. 4(1): 7192. 